Journal of Applied Pharmaceutical Science Vol. 6 (09), pp. 082-086, September, 2016

Available online at http://www.japsonline.com

DOI: $10.7324 / J A P S .2016 .60912$

ISSN 2231-3354 (cc) BY-NC-SA

\title{
Phytochemical, nutritional and antioxidant capacity of five Ivorian edible leaves aqueous extracts
}

\author{
Marcel Koffi Konan ${ }^{1 *}$, Emmanuel N'Dri Koffi ${ }^{1,2}$, Ibrahima Cisse ${ }^{3}$, Augustin Amissa Adima ${ }^{3}$, Yves-Alain Bekro ${ }^{2}$ \\ ${ }^{1}$ Laboratoire de Chimie Bio-Organique et de Substances Naturelles, UFR SFA, Université Nangui Abrogoua, 02 BP 801 Abidjan 02, Côte d'Ivoire. \\ ${ }^{2}$ Ecole Normale Supérieure (ENS), Département des Sciences et Technologie, 08 BP 10 Abidjan 08. ${ }^{3}$ INP-HB, Laboratoire de Procédés Industriels, \\ de Synthèse, de l'Environnement et des Energies Nouvelles (LAPISEN), BP 1093 Yamoussoukro, Côte d'Ivoire.
}

\begin{tabular}{|c|c|}
\hline ARTICLE INFO & ABSTRACT \\
\hline Article history: & \multirow{9}{*}{$\begin{array}{l}\text { Boiled aqueous extract from five Ivorian edible leaves (Solanum scabrum, Ipomea batatas, Corchorus olitorius, } \\
\text { Basella alba, Hibiscus sabdariffa) have been analyzed for their antioxidant contents, phytochemical and } \\
\text { nutritional compositions. I. batata extract showed the highest amount of antioxidant }(167.52 \mu \mathrm{g} / 100 \mathrm{gTE}) \text {, total } \\
\text { polyphenol }(34.18 \mathrm{mg} / 100 \mathrm{~g} \text { TE) and total flavonoid }(12.67 \mathrm{mg} / 100 \mathrm{~g} \mathrm{TE}) \text {. The higher energy value }(225.5 \mathrm{kcal}) \\
\text { was obtained in } S \text {. scrabrum extract. The highest amount of zinc and potassium were found in } S \text {. scrabrum } \\
\text { extract }(0.28 \text { and } 362.1 \mathrm{mg} / 100 \mathrm{~g} \mathrm{DW} \text {; respectively). Maximum amount of copper }(1.16 \mathrm{mg} / 100 \mathrm{~g} \mathrm{DW} \text { and } \\
\text { calcium }(777.9 \mathrm{mg} / 100 \mathrm{~g} \mathrm{DW}) \text { were obtained in } \text { H. sabdariffa extract. The highest content of iron }(49.81 \\
\mathrm{mg} / 100 \mathrm{~g} \mathrm{DW}) \mathrm{and} \text { magnesium }(201 \mathrm{mg} / 100 \mathrm{~g} \text { DW) were observed in } B \text {. alba extract. The highest content of } \\
\text { sodium ( } 2.39 \mathrm{mg} / 100 \mathrm{~g} \text { DW) was obtained in } C \text {. olitorius extract. All extracts contained secondary metabolites } \\
\text { such as polyphenols (tannins, flavonoids), sterols and terpenes, which have medicinal potent. }\end{array}$} \\
\hline Received on: 02/05/2016 & \\
\hline Revised on: 17/07/2016 & \\
\hline Accepted on: 04/08/2016 & \\
\hline Available online: $26 / 09 / 2016$ & \\
\hline Key words: & \\
\hline Edible leaves, antioxidant, & \\
\hline phytochemical and & \\
\hline nutritional compositions. & \\
\hline
\end{tabular}

\section{INTRODUCTION}

Different parts of plants were used in human diet since prehistoric times. In fact, traces of edible leaves have been found in ancient Egyptian archaeological sites. Some edible leaves were historically documented in ancient Greece, in ancient Rome (Thurstan et al., 1994). In sub-Saharan Africa, there are more than 45,000 plant species; a thousand can be consumed as such (Maundu et al., 1993). Ivorian flora includes several edible wild species known by populations (Ambe, 2005). They play an important role in agriculture and in food thereby generating significant income both in rural and urban areas. They are important sources of vitamins, minerals, proteins, fibers and carbohydrates and thus contribute to improve the nutritional status of populations. Some edibles plants have medicinal properties and are used to treat various diseases (malaria,

\footnotetext{
* Corresponding Author

Email:konanm2@gmail.com
}

intestinal parasites, infection etc.) (Stevels, 1990; Mnzava, 1997; Chweya and Eyzaguirre, 1999; Schippers, 2004). Free radicals are atoms or group of atoms that have one or more unpaired electrons. When their production becomes excessive in the body, we are talking about oxidative stress. A role of oxidative stress has been postulated in many diseases, including diabetes mellitus, agerelated eye disease, and neurodegenerative diseases such as Parkinson's disease and many others (Stefanis et al., 1997; Rao et al., 2006). Unfortunately, the antioxidants produced naturally are not enough to neutralize all of the free radicals in the body. Therefore, a constant supply of external sources of antioxidants should be a part of one's daily diet, in order to reduce oxidative stress and related damage. The oxidative effects of free radicals could be annihilating by consumption of edible plants rich in trace elements and polyphenols. The present study, therefore investigated the in vitro antioxidant activity and chemical compositions of boiled aqueous extract from five Ivorian edible leaves (Solanum scabrum, Ipomea batatas, Corchoruus olitorius, Spinacia oleracea, Hibiscus sabdariffa) used as soop. 


\section{EXPERIMENTAL SECTION}

\section{Plant collection and extract preparation}

Five edibles leaves usually eat by Ivorian were purchased in market of Yamoussoukro (Côte d'Ivoire). There are Solanum scabrum (Solanaceae), Ipomea batatas (Convolvulaceae), Corchoruus olitorius (Tiliaceae), Basella alba (Basellaceae) and Hibiscus sabdariffa (Malvaceae). The plants specimen were authentified by botanist (Centre National de Floristique, C.N.F) located at the University of Félix HOUPHOUËT-BOIGNY (Côte d'Ivoire).

After collecting, leaves were dried at $18^{\circ} \mathrm{C}$ in laboratory during two weeks. The dried leaves were reduced in fine powders and packed in sealed bags until analysis. Aqueous extracts were obtained after boiling at $100^{\circ} \mathrm{C}$ in $250 \mathrm{~mL}$ distilled water and filtering $5 \mathrm{~g}$ of crushed leaves for $30 \mathrm{~min}$.

\section{Phytochemical study}

The phytochemical study, based on color and / or precipitation tests was carried out on aqueous extracts from leaves of five edible plants (Bagre et al., 2007). Target molecules families of this screening were polyphenols (tannins, flavonoids, anthocyanins), saponins, steroids, terpenoids and alkaloids.

\section{Total polyphenol content}

Total polyphenol content was determined by colorimetry, using the Folin-Ciocalteu's (F-C) method (Singleton and Rossi, 1965; Wood et al., 2002). Diluted F-C reagent (1/10, v/v, $2.5 \mathrm{~mL})$ was added to $30 \mu \mathrm{L}$ of sample in a capped glass tube. After 2 min of incubation in the dark at room temperature, $2 \mathrm{~mL}$ of aqueous sodium carbonate $\left(75\right.$ g.L $\left.\mathrm{L}^{-1}\right)$ was added. After gentle stirring, the mixture was placed in a water bath at $50{ }^{\circ} \mathrm{C}$ for $15 \mathrm{~min}$ and rapidly cooled down to stop the reaction. Absorbance was measured at $\lambda \max =760 \mathrm{~nm}$ using a UV-visible spectrophotometer (Jasco V530, Japan). Total polyphenol content was expressed as gallic acid equivalent (mg/100 g dry weight). Samples were analyzed in triplicate.

\section{Total flavonoid content}

The total flavonoid content was determined by the aluminum chloride colorimetric method described by Marinova et al., (2005). In a $25 \mathrm{~mL}$ volumetric flask, $0.75 \mathrm{~mL}$ of $\mathrm{NaNO}_{2}$ distilled water solution $(5 \%, \mathrm{w} / \mathrm{v})$ was added to $2.5 \mathrm{~mL}$ aliquot of the sample. The color reaction was left to develop for $5 \mathrm{~min}$ in the dark and at room temperature. Then, $0.75 \mathrm{~mL}$ of $\mathrm{AlCl}_{3}$ distilled water solution $(10 \%, \mathrm{w} / \mathrm{v})$ and $5 \mathrm{~mL} \mathrm{NaOH}$ solution $(1 \mathrm{M})$ were successively added to the flask. The mixture was diluted to the mark with distilled water. After gentle mixing, the solution absorbance was measured at $\lambda \max =510 \mathrm{~nm}$. The total flavonoid content was expressed as quercetin equivalent $(\mathrm{mg} / 100 \mathrm{~g}$ dry weight). Samples were analyzed in triplicate.

\section{Trolox equivalent antioxidant capacity (TEAC) using ABTS ${ }^{\circ+}$ radical-scavenging assay}

Antioxidant capacity was determined using the procedure reported by Koffi et al. (2013). The ABTS•+ solution was prepared by mixing equal volumes of $\mathrm{ABTS}^{\cdot+}$ salt solution (87.7 $\mathrm{mg}$ salt in $20 \mathrm{~mL}$ distilled water, $\left.8 \mathrm{mmol} . \mathrm{L}^{-1}\right)$ and potassium persulphate $\left(\mathrm{K}_{2} \mathrm{~S}_{2} \mathrm{O}_{8}\right)$ solution $\left(1.6210^{-3} \mathrm{~g}\right.$ salt in $20 \mathrm{~mL}$ distilled water, $\left.3 \mathrm{mmol} \cdot \mathrm{L}^{-1}\right)$. The final $40 \mathrm{~mL}$ stock solution obtained was kept at room temperature in the dark for 16 hours before use. The volume of stock solution needed for TEAC assay was first diluted with methanol in order to obtain an absorbance of 0.7 at $\lambda \max =$ $734 \mathrm{~nm}$. A sample volume of $0.1 \mathrm{~mL}$ was mixed with $3.9 \mathrm{~mL}$ of diluted $\mathrm{ABTS}^{\circ+}$ stock solution and the mixture was incubated for 6 min exactly, in the dark at $30{ }^{\circ} \mathrm{C}$. Absorbance was measured at $\lambda \max =734 \mathrm{~nm}$, and had to be higher than $20 \%$ of the absorbance of the diluted $\mathrm{ABTS}^{\circ+}$ stock solution itself, otherwise the sample solution had to be diluted accordingly. Pure Methanol was used as a blank solution. TEAC was expressed as trolox equivalent (mg/100 g dry weight). Samples were analyzed in triplicate.

\section{Mineral analysis}

Aqueous extracts were analyzed for $\mathrm{Zn}, \mathrm{Ca}, \mathrm{Cu}, \mathrm{Fe}, \mathrm{Mg}$, $\mathrm{Na}$ and $\mathrm{K}$ contents using a flame atomic absorption photometer (Varian AA 20 Spectrometer, Australia). The concentration or level of each element was determined by reference to a calibration curve.

\section{Proximate analysis}

The proximate analyses were carried out in triplicates and the results obtained were average value. The estimation of protein, lipid and fiber contents from aqueous leaves was performed using AOAC method (Cunniff, 1999). Carbohydrate content was carried out using Phenol-Sulfuric Acid method (Dubois et al., 1956; Agbo et al., 1996).

\section{Determination of energy or calorific value}

The total energy value $(\mathrm{kcal} / 100 \mathrm{~g})$ of dry leaves was estimated using the method described by FAO (2002) as shown below:

Energy value $=(\%$ protein $x 4)+(\%$ lipid $x 9)+(\%$ carbohydrate $\mathrm{x} 4)$

\section{Statistical analysis}

Results were expressed as mean \pm standard deviation of three replicate. Data were evaluated by one way analysis of variance (ANOVA) using statistica 7.1 (StatSoft, Inc, USA) solfware. Newman-keuls test performed to determine significant.

\section{RESULTS AND DISCUSSION}

\section{Phytochemical screening}

The phytochemical screening of aqueous extracts from five Ivorian edibles leaves revealed presence of polyphenols (tannins, flavonoids), steroids and terpenoids (Table 1). Consumption of polyphenols has been linked to lowered risks of many chronic diseases including cancer, cardiovascular diseases, chronic inflammation and many degeneration diseases (Tsao, 2010). Increasing numbers of terpenoids are being found to have 
antibacterial, anti-malarial, anti-inflammatory and anti-cancer activities (Mahato and Sen, 1997).

Table 1: Phytochemical screening of aqueous extract from five Ivorian edible leaves.

\begin{tabular}{|c|c|c|c|c|c|c|c|}
\hline \multirow[b]{2}{*}{ 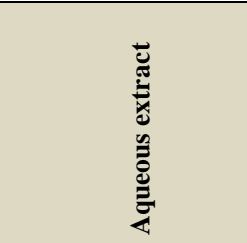 } & \multicolumn{4}{|c|}{ Polyphenols } & \multirow[b]{2}{*}{$\frac{\frac{\mathscr{e}}{\frac{0}{\pi}}}{\frac{\tilde{J}}{2}}$} & \multirow[b]{2}{*}{ 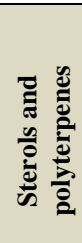 } & \multirow[b]{2}{*}{ 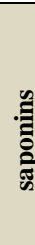 } \\
\hline & 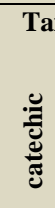 & $\stackrel{\circlearrowright}{\stackrel{\Xi}{\overparen{E}}}$ & $\frac{0}{\frac{0}{0}}$ & 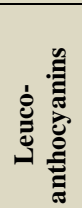 & & & \\
\hline Solanum scabrum & + & + & + & + & - & + & + \\
\hline Ipomea batatas & + & + & + & + & - & + & + \\
\hline Corchoruus olitorius & + & + & + & + & - & + & + \\
\hline Basella alba & - & + & + & - & - & + & + \\
\hline Hibiscus sabdariffa & + & - & + & + & - & + & - \\
\hline
\end{tabular}

In this study, aqueous extracts did not show a presence of alkaloids. Saponins were detected in all aqueous extracts excepted H. sabadariffa extract. Saponins are also important in human nutrition. Several biological effects have been ascribed to saponins, such as membrane-permeabilising, immunostimulant, hypocholesterolaemic and anticarcinogenic properties (Francis et al., 2002). The presence of bioactive compounds in these extract indicate their medicinal value.

\section{Phytochemical composition and antioxidant capacity}

Figure 1 presents antioxidant capacity of aqueous extract from five Ivorian edible leaves. The extract of Ipomea batatas presented the highest antioxidant capacity (16.75 mg/ $100 \mathrm{~g} \mathrm{DW})$ followed by that of Corchoruus olitorius ( $8.79 \mathrm{mg} / 100 \mathrm{~g} \mathrm{DW})$, Hibiscus sabdariffa (6.31 mg/ 100 g DW), Solanum scabrum (6.21 $\mathrm{mg} / 100 \mathrm{~g} \mathrm{DW})$ and Basella alba (1.71 mg/ $100 \mathrm{~g} \mathrm{DW})$.

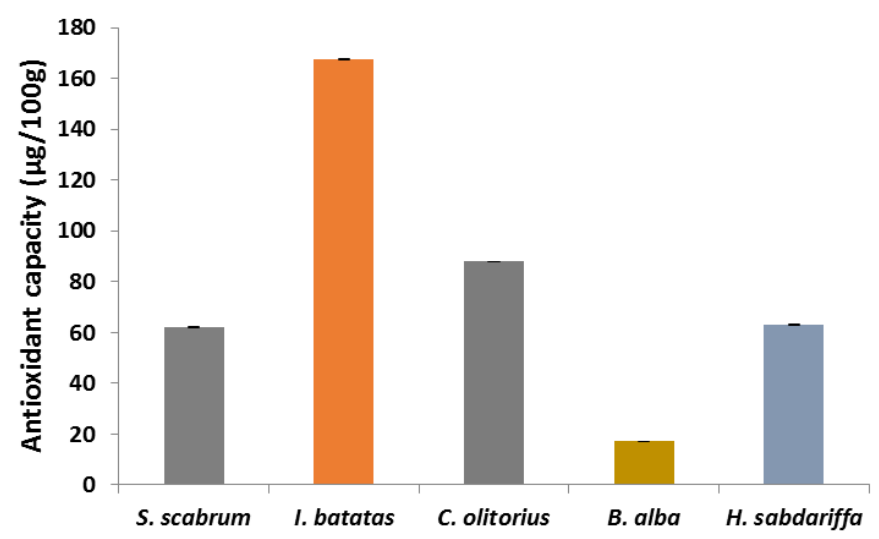

Fig. 1: Antioxidant capacity from five Ivorian edible leaves

The good antioxidant properties from Ipomea batatas was already reported by Panda and Sonkamble (2012). The content of total polyphenols and total flavonoids of these aqueous extract are shown in figure 2 . These compounds are in agreement with antioxidant capacity from aqueous extract. This result confirmed antioxidant properties of polyphenols (Balasundram et al., 2006; Dai and Mumper, 2010). Polyphenolic antioxidants from dietary sources are frequently a topic of interest due to widespread scientific agreement that they may help lower the incidence of certain cancers, cardiovascular and neurodegenerative diseases, and DNA damage and even may have antiaging properties (Obrenovich et al., 2010). They played a role in prevention of degenerative diseases, particularly cardiovascular diseases and cancers (Scalbert et al., 2005).

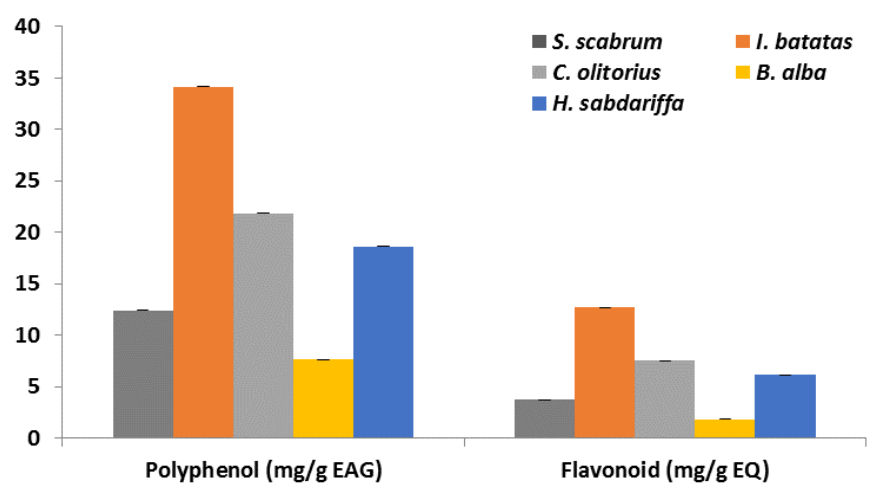

Fig. 2: Total polyphenol and total flavonoid contents from five Ivorian edible leaves.

\section{Nutritional composition of aqueous leaves}

Figure 3 presents the result for macro-nutrients of aqueous extracts from five Ivorian edible leaves.

The higher value of protein was $31.58 \mathrm{~g} / 100 \mathrm{~g} \mathrm{DW}$ in Solanum scabrum extract and the lowest was $19.07 \mathrm{~g} / 100 \mathrm{~g} \mathrm{DW}$ in Hibiscus sabdariffa with the following decreasing order: Solanum scabrum > Basella alba > Corchoruus olitorius > Ipomea batatas $>$ Hibiscus sabdariffa. So, S. scabrum could be used as food protein supplement.

$C$. olitorius contained the highest lipid contents (1.4 $\mathrm{g} / 100 \mathrm{~g} \mathrm{DW}$ ) followed by $S$. scabrum, H. sabdariffa, B. alba and I. batatas (1.36, 1.15, 1.14, 0.74 g/100 g DW; respectively). High contents of lipid in human diet are principal sources of obesity and other relative diseases. Dietary fat composition can interfere in the development of obesity due to the specific roles of some fatty acids that have different metabolic activities, which can alter both fat oxidation and deposition rates, resulting in changes in body weight and/or composition (Coelho et al., 2011). H. sabdariffa, $S$. scabrum and B. alba have the higher fiber contents; the lower fiber contents were observed in $C$. olitorius extract. Carbohydrate of aqueous extract from selected Ivorian edible leaves range between 19.75 and $29.87 \mathrm{~g} / 100 \mathrm{~g}$ DW. The decreasing order has below: Hibiscus sabdariffa > Corchoruus olitorius > Ipomea batatas > Solanum scabrum > Basella alba. The result showed that $S$. scabrum extract has higher energy value when compared to others. The aqueous extract of $B$. alba, despite presented the lowest energy value. So, S. scrabrum extract could be food supplement. 


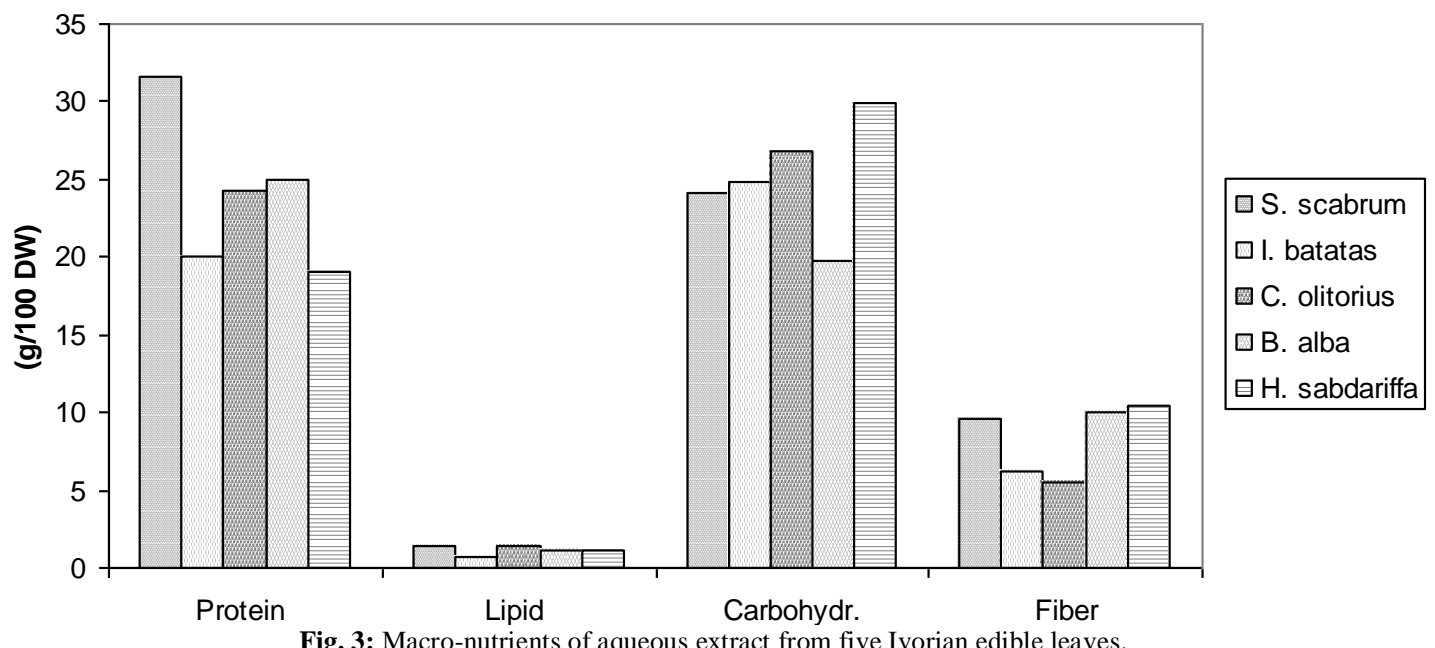

Table 2: Micro-nutrients of aqueous extract from five Ivorian edible leaves.

\begin{tabular}{|c|c|c|c|c|c|c|c|}
\hline Dry leaves (100 g) & $\mathbf{Z n}(\mathrm{mg})$ & Ca $(\mathrm{mg})$ & $\mathrm{Cu}(\mathrm{mg})$ & $\mathbf{F e}(\mathrm{mg})$ & $\mathbf{M g}(\mathrm{mg})$ & $\mathbf{N a}(\mathrm{mg})$ & $\mathbf{K}(\mathrm{mg})$ \\
\hline S. scabrum & $0.28 \pm 0.01^{\mathrm{d}}$ & $122.2 \pm 0.02^{\mathrm{a}}$ & $1.14 \pm 0.09^{\mathrm{c}}$ & $34.11 \pm 0.15^{\mathrm{d}}$ & $77.5 \pm 0.24^{\mathrm{d}}$ & $1.63 \pm 0.01^{\mathrm{c}}$ & $362.1 \pm 0.31^{\circ}$ \\
\hline I. batatas & $0.21 \pm 0.00^{\mathrm{b}}$ & $183.0 \pm 0.20^{\mathrm{b}}$ & $1.10 \pm 0.00^{\mathrm{c}}$ & $17.98 \pm 0.15^{\mathrm{c}}$ & $8.5 \pm 0.07^{\mathrm{a}}$ & $1.43 \pm 0.01^{\mathrm{b}}$ & $251.7 \pm 0.21^{\mathrm{b}}$ \\
\hline C. olitorius & $0.25 \pm 0.01^{\mathrm{c}}$ & $194.0 \pm 0.45^{\mathrm{c}}$ & $0.86 \pm 0.01^{\mathrm{b}}$ & $12.67 \pm 0.13^{\mathrm{a}}$ & $23.5 \pm 0.02^{\mathrm{b}}$ & $2.39 \pm 0.00^{\mathrm{e}}$ & $267.3 \pm 0.18^{\circ}$ \\
\hline B. alba & $0.05 \pm 0.00^{\mathrm{a}}$ & $202.2 \pm 0.01^{\mathrm{d}}$ & $0.61 \pm 0.00^{\mathrm{a}}$ & $49.81 \pm 0.00^{\mathrm{e}}$ & $201.0 \pm 0.08^{\mathrm{e}}$ & $1.76 \pm 0.00^{\mathrm{d}}$ & $345.5 \pm 0.19^{\mathrm{d}}$ \\
\hline H. sabdariffa & $0.26 \pm 0.00^{\mathrm{c}}$ & $777.9 \pm 0.14^{\mathrm{e}}$ & $1.16 \pm 0.00^{\mathrm{c}}$ & $14.47 \pm 0.01^{\mathrm{b}}$ & $40 \pm 0.00^{c}$ & $1.39 \pm 0.02^{\mathrm{a}}$ & $136.6 \pm 0.01^{\mathrm{a}}$ \\
\hline
\end{tabular}

For each column, letters equals indicate that the means difference is not significant at $p<0.05$.

The present study also investigated micro-nutrients such as zinc $(\mathrm{Zn})$, calcium $(\mathrm{Ca})$, copper $(\mathrm{Cu})$, iron $(\mathrm{Fe})$, magnesium $(\mathrm{Mn})$, sodium $(\mathrm{Na})$ and potassium $(\mathrm{K})$. Table 2 shows their mean concentration. These micro-nutrients are very important in the body. Zinc is necessary for the growth and multiplication of cells, skin integrity, bone metabolism, and functioning of taste and eyesight (Varsha et al., 2012). Zn is also an anti-inflammatory and antioxidant agent (Prasad, 2009). Calcium is important for construction and maintenance of bone and normal function of nerves and muscles (Soetan et al., 2010). Copper is essential for maintaining the strength of the skin, blood vessels, epithelial and connective tissue throughout the body. Iron plays a role in the production of hemoglobin, myelin, melanin and it also keeps thyroid gland functioning normally (Osredkar and Sustar, 2011). Iron is essential for haemoglobin formation, normal functioning of central nervous system and in the oxidation of carbohydrates, protein and fats (Adeyeye and Otokili, 1999). The deficiencies of magnesium are unusual but may lead to bone deformities, rashes, reduced hair growth (Varsha et al., 2012). Sodium and potassium are important in the maintenance of osmotic balance between cells and the interstitial fluid (Soetan, Olaiya et al., 2010). The highest amount of zinc was found in S. scrabrum extract $(0.28 \mathrm{mg} / 100 \mathrm{~g}$ DW) followed in decreasing order by $H$. sabdariffa $>C$. olitorius $>$ I. batatas > B. alba. Important content of Ca $(777.9 \mathrm{mg} / 100 \mathrm{~g}$ DW) was obtained in $H$. sabdariffa extract followed by that of $B$. alba, C. olitorius, I. batatas and S. scrabrum. The highest copper content $(1.16 \mathrm{mg} / 100 \mathrm{~g} \mathrm{DW})$ was determined in $H$. sabdariffa extract and the lower value $(0.61 \mathrm{~g} / 100 \mathrm{~g} \mathrm{DW})$ was obtained from B. alba. The highest and lowest iron content (49.81 and $12.67 \mathrm{~g} / 100 \mathrm{~g} \mathrm{DW}$ ) were obtained from $B$. alba and C. olitorius, respectively. B. alba $(201 \mathrm{mg} / 100 \mathrm{~g} \mathrm{DW})$ have high magnesium content; I. batatas with $8.5 \mathrm{mg} / 100 \mathrm{~g} \mathrm{DW}$ has minimum $\mathrm{Mg}$ content. The maximum $(2.39 \mathrm{mg} / 100 \mathrm{~g} \mathrm{DW})$ and minimum $(1.39 \mathrm{mg} / 100 \mathrm{~g} \mathrm{DW})$ sodium contents were for $C$. olitorius and $H$. sabdariffa, respectively. Medium sodium contents were $1.76,1.63$ and $1.43 \mathrm{mg} / 100 \mathrm{~g}$ for B. alba, S. scrabrum and $I$. batatas, respectively.

\section{CONCLUSION}

This study revealed that boiled aqueous extract from Ipomea batatas represents a promising sources of phenolic antioxidants. The five edibles leaves contain phytochemicals such as tannins, flavonoids, sterols and terpenes. These leaves extracts contain again saponins and leuco-anthocyanins in all the plant extracts excepted Hibiscus sabdariffa and Basella alba extracts. Phytochemicals found in aqueous extract could be benefits for human health. The results indicate also that studied leaves contained macronutrients and micronutrients. It could therefore be concluded that studied edibles leaves can contribute to supplement other major nutrients source using by human.

\section{Financial support and sponsorship: Nil.}

Conflicts of interest: There are no conflicts of interest.

\section{REFERENCES}

Adeyeye E.Otokili M. K. O. Proximate composition and some nutritionally valuable minerals of two varieties of Capsicum annum (Bell and cherry peppers), Discov. Innov. 1999; 11: 75-81. 
Agbo N. G., Soumanou M.Yao K. A. Nouvelles techniques de conservation de la banane plantain en milieu rural avec de la matière végétale, Sciences des Aliments. 1996; 16(6): 607-621.

Ambe G. A. Les fruits sauvages comestibles des savanes guinéennes de Cote d'ivoire : état de la connaissance par une population locale, les Malinké, Biotechnol. Agro. Soc. Environ. 2005; 5(1): 43-58.

Bagre I., Bahi C., Gnahoue G., Djaman A. J.Guede G. F. Composition phytochimique et évaluation in vitro de l'activité antifongique des extraits des feuilles Morinda morindoides (baker) milneredhead (rubiaceae) sur Aspergillus fumigatus et Candida albicans, Journal of Sciences Pharmacology and Biology. 2007; 8(1): 1523.

Balasundram N., Sundram K.Samman S. Phenolic compounds in plants and agri-industrial by-products: antioxidant activity, occurence, and potential uses, Food Chem. 2006; 99: 191-203.

Chweya J. A.Eyzaguirre P. The biodiversity of traditional leafy vegetables, IPGRI Rome (Italy). 1999: 182.

Coelho D. F., Pereira-Lancha L. O., Chaves D. S., Diwan D., Ferraz R., Campos-Ferraz P. L., Poortmans J. R.Lancha A. H. J. Effect of high-fat diets on body composition, lipid metabolism and insulin sensitivity, and the role of exercise on these parameters, Brazilian Journal of Medical and Biological Research 2011; 44: 966-972.

Cunniff P. Official methods of analysis of AOAC International.,Washington, D.C. 1999: 16. ed., 5rd. Rev.

Dai J.Mumper R. J. Plant phenolics: extraction, analysis and their antioxidant and anticancer properties, Molecules. 2010; 15(10): 7313-7352.

Dubois M., Gilles K., Hamilton J., Rebers P.Smith F. Colorimetric method for determination of sugars and related substances, Analytical Chemistry. 1956; 28(3): 350-356.

FAO. Food energy - methods of analysis and conversion factors. Food And Nutrition Paper 77, 2002, 93p.

Francis G., Kerem Z., Makkar H. P. S.Becker K. The biological action of saponins in animal systems: a review, British Journal of Nutrition. 2002; 88: 587-605.

Koffi E. N., Le Guernevé C., Lozano P. R., Meudec E., Adjé F. A., Bekro Y.-A.Lozano Y. F. Polyphenol extraction and characterization of Justicia secunda Vahl leaves for traditional medicinal uses, Industrial Crops and Products. 2013; 49: 682-689.

Mahato S. B.Sen S. Advances in triterpenoid research, 19901994, Phytochemistry. 1997; 44: 1185-1236.

Marinova D., Ribavora F.Antanassova M. Total phenolics in bulgarian fruits and vegetables, J. Univ. Chem. Technol. Met. 2005; 40(3): 255-260.

Maundu P. M., Kabuye C. H. S.Chweya J. A. 1993. Proceedings of the Indigenous Food Plants Workshop, National Museums of Kenya, Nairobi.

Mnzava N. A. 1997. Proceedings of the IPGRI international workshop on genetic resources of traditional vegetables in Africa: conservation and use. Vegetable crop diversification and the place of traditional species in the tropics. N. ICRAF-HQ: 1-15.

Obrenovich M. E., Nair N. G., Beyaz A., Aliev G.Reddy V. P. The Role of Polyphenolic Antioxidants in Health, Disease, and Aging, Rejuvenation Research 2010; 13(6): 1-13.
Osredkar J.Sustar N. Copper and Zinc, Biological Role and Significance of Copper/Zinc Imbalance, J Clinic Toxicol. 2011; S3(001): $1-18$.

Panda V.Sonkamble M. Phytochemical constituents and pharmacological activities of Ipomea batatas 1. (Lam) - Review, International Journal of Research in Phytochemistry and Pharmacology. 2012; 2(1): 25-34

Prasad M. D. A. S. Impact of the Discovery of Human Zinc Deficiency on Health, Journal of the American College of Nutrition. 2009; 28(3): 257-265.

Rao A. L., Bharani M.Pallavi V. Role of antioxidants and free radicals in health and disease, Adv Pharmacol Toxicol. 2006; 7: 29-38.

Scalbert A., Johnson I. T.Saltmarsh M. Polyphenols: antioxidants and beyond, Am J Clin Nutr. 2005; 81(suppl): 215S-217S

Schippers R. R. 2004. Légumes Africains Indigènes. Pays-Bas: Présentation des espèces cultivées,

Singleton V. L.Rossi J. A. Colorimetry of total phenolics with phosphomolybdic-phosphotungstic acid reagents, Am. J. Enol.Viticult 1965; 16: 144-158.

Soetan K. O., Olaiya C. O.Oyewole O. E. The importance of mineral elements for humans, domestic animals and plants: A review, African Journal of Food Science. 2010; 4(5): 200-222.

Stefanis L., Burke R. E.Greene L. A. Apoptosis in neurodegenerative disorders, Curr Opin Neurol. . 1997; 10: 299-305.

Stevels J. M. C. Légumes traditionnels du Cameroun: une étude agrobotanique, Wageningen, the Netherlands Papers $\mathrm{N}^{\circ} 90.1990$.

Thurstan S., Andah B., Okpoko A.Sinclair P. The Archaeology of Africa: Food, Metals and Towns, One World Archaeology, Routlege. 1994: 886

Tsao R. Chemistry and biochemistry of dietary polyphenols, Nutrients. 2010; 2(12): 1231-1246.

Varsha R., Shivprasad M.Sujata V. Nutritional assessment of some selected wild edible plants as a good source of mineral, Asian Journal of Plant Science and Research. 2012; 2(4): 468-472.

Wood J. E., Senthilmohan S. T.Peskin A. V. Antioxidant activity of procyanidin-containing plant extracts at different pHs, Food Chem. 2002; 77(2): 155-161.

\section{How to cite this article:}

Konan MK, Koffi EN, Cisse I, Adima AA, Bekro YA. Phytochemical, nutritional and antioxidant capacity of five Ivorian edible leaves aqueous extracts. J App Pharm Sci, 2016; 6 (09): 082086. 